\title{
Code-Mixing in Narrative Essay of Fifth Grade Students
}

\author{
Carolin Eninta Ginting and Rahman \\ Postgraduate School of Primary Education, Indonesia University of Education, Jl. DR. Setiabudi \\ No. 229, Bandung, West Java, Indonesia \\ olin.redninth@gmail.com
}

\begin{abstract}
This study aims to find out the code-mixing in narrative essays of grade $5^{\text {th }}$ primary school and what factor is behind the use of code-mixing. This study is done in one of the school in Lembang sub-district which is most of the students are coming from provinces in Indonesia. Method of this study is descriptive analysis. The instrument of this study is a written test by giving an assignment to make a narrative essay. This study uses data analysis technique to analyze word by word, sentence, and phrase which contain code-mixing. This study states that some students' narrative essays contain code-mixing. There are 8 narrative essays contain code-mixing. It is found that students mix Indonesian language and English, Indonesian language and local language such as Betawi and Sundanese, and formal and informal language. The factors of code-mixing in those narrative essays are the speaker and his personality, limitation of code, habituation, and more popular terms.
\end{abstract}

Keywords: bilingualism, code, Indonesian subject, narrative essay

\section{Introduction}

The use of more than one language can lead to language phenomenon. That language phenomenon can be bilingualism or multilingualism. It is stated by Johan [1] that the phenomenon of bilingualism is one of the manifestation of linguistic symptoms. Bilingualism does not only talk about the use of more than two languages fluently but also the ability of speaker to use those languages in communication [2]. Bilingualism occurs because of the presence of two or more languages that often contact in the language-speaking community in Indonesia.

Language contact is the use of more than one language at the same place and time when interacting with other people. Direct language contact affects language users in using and choosing variation language [3]. The activity of language contact can bring the changing of one language to other language are related [4]. Language contact can happen between local language and local language or local language and Indonesian language. Indonesian language contact with local language is unavoidable because the two languages coexist. Language contact is also difficult to avoid if the two languages are well not mastered [5]. Language contacts that result in bilingualism often occur in the interactions of daily life and the world of education. In education, the use of bilingualism not only occurs in spoken language but also in written language. Bilingualism is found in students' written which is narrative essay. From earlier 
research was done by Suparlan [6], it is found that narrative essays grade $4^{\text {th }}$ of SDN Balongcabe, Kedungadem sub-district, Bojonegoro district contain language phenomenon which is mixed language between Indonesian and Javanese language or called code-mixing. Code-mixing occurs when a speaker uses language predominantly,

Code-mixing is a change from one language to another with speech [7]. Code-mixing usually relates to the speaker characteristic such as social background and education level. Prominent feature of code-mixing is used in formal situation. Based on the origin of its absorption, code-mixing is divided into three types, which are inner code-mixing, outer code-mixing, hybrid code-mixing.

Inner code-mixing is code-mixing that absorbs the native language element that is still a relative, for example in Indonesia mixes with Javanese or Sundanese. Outer codemixing is code-mixing that absorbs English, for example in Indonesia mixes with English, Dutch, or Japanese. Moreover, hybrid code-mixing is code-mixing that absorbs both local language and foreign language.

According to Suandi [8], factors that cause code-mixing are limitation of code, the use of more popular term, speaker and his characteristic, talk partner, place of living and time when speaking, topic, function and purpose, variety and level of speech, the presence of third speakers, topic of discussion, to arouse a sense of humor, and for prestige.

From the problem can be seen that students have not been able yet to use Indonesian language well and correctly in their narrative essays. Based on that background, the use of code-mixing in students' narrative essay is interested and need to be more researched. This problem is interested because it is a must for student to use Indonesian language well and correctly in narrative essay. According to Indrayani [9] that negative impact on using code-switching and code-mixing in learning process can distract the purpose of learning mainly to obtaining Indonesian language skill which is student cannot be differentiate the use of Indonesian in the classroom or outside classroom, formal or informal situation and low mastery of vocabulary in Indonesian.

\section{Research Methods}

\subsection{Research Approach}

This study has a purpose to find out, analysis, and describe code-mixing in students' narrative essay. To achieve that purpose is needed the right approach to get the accurate information. The right approach is qualitative.

\subsection{Methods}

Method is used in this study is descriptive analysis. Descriptive analysis has three main scopes which are collecting data, analyzing data, and presenting the result [8]. Data in this study is narrative essays contain code-mixing. 


\subsection{Participant and Research Sites}

In qualitative research, the chosen of participant is done by purposive sampling approach. This approach emphasizes the chosen of participants and the research sites are based on the needs of researcher. In this study the participant is fifth grade students. Researcher chooses fifth grade students because they have already learnt about narrative essay. That's why it is important to see the ability of using Indonesia in their narrative essay. This study took place at SDN 1 Kayuambon Lembang. The reason of choosing this school is because this school is a literacy school model and its students come from all over provinces in Indonesia.

\subsection{Data}

The type of data used in this study is qualitative data. Qualitative data is the type of data that is not number, but the data is sentence, phrase, and word.

\subsection{Data Collection Technique}

Collecting data is very important steps in this study that the researcher can collect a valid data. Data is collected by interview and document. Interview is done with principal as a stakeholder at school and homeroom teacher who also teacher Indonesian subject at grade 5. Student is given a task to make a narrative essay with a theme is "My Experience", they have to write an essay at least 4 paragraphs.

\section{Research and Discussion}

\subsection{Document Results}

The result of this study regarding to code-mixing analysis in students' narrative essay is found that students still use two languages in their narrative essay. From 38 narrative essays, there are 8 narrative essays contain code-mixing. Here is the data which contains code-mixing.

Data 1

Cal, lo mau ikut ga ke Moria Café pas pulang sekolah?

Tapi seru juga sih, gua bisa have fun bareng temen-temen.

(Cal, do you want to go to Moria café after school?)

(But, it's fun; I can have fun with some friends.)

From data above, it is found that there is inner code-mixing. Student mixes formal language to informal language. It can be seen from the words lo (you), gua (I), have fun bareng temen-temen (have fun with friends). Factor that caused this student mix his language is speaker and his personality. Speaker who writes this essay comes from Jakarta. People in Jakarta usually speak Betawi language in daily life.

Data 2

Aku senang sekali sekelompok dengan Rozan. Kita main bareng, jajan bareng, nulis bareng, berbagi cerita, dll.

(I am very happy with the group of Rozan. We play together, buy snack together, write together, share story, etc) 
In this data, student mixes from formal language to informal language. It can be seen from the word bareng (together). The right word for bareng is bersama. Furthermore, there is also Sundanese word in nulis (write). The right word for nulis is menulis (write). Factor that causes the choosing code-mixing is limitation of using code.

Data 3

Tah pas pulang dari pasar saya dan teman-teman tidak pulang dulu tapi kita ke alunalun dulu.

(When coming home from market, my friends and I did not go home first but we went to city square)

From data above it is found inner code-mixing in the word tah pas (when). This word is from Sundanese. The correct word in Indonesian language is ketika (when). Student mixes his language because of his habituation. In Sundanese speaking, people usually say that word in the beginning of their sentence.

Data 4

Saat main game kita main game sampai maghrib.

(When we play a game, we play until maghrib).

From data above, it shows that there is outer code-mixing. Student mixes Indonesian and English. The correct sentence is 'saat bermain permainan, kita bermain sampai maghrib.' Student mixed with English because a word game is popular term.

Data 5

Aku ingin menjadi novelist, itu hanya impian tapi sampai sekarang aku enggak bisa bikin cerita pendek (cerpen).

(I want to be a novelist, that is only a dream but I cannot make a short story)

Data 5 shows that there is a code-mixing from formal to informal language. It is found the words enggak (no) and bikin (make) which have been used in informal speaking. The correct sentence, it should be 'Aku ingin menjadi novelist, itu hanya impian tapi sampai sekarang aku belum bisa membuat cerita pendek.' Factor that causes the student mixes to informal language because his habituation. When we speak in informal situation, we tend to use those words.

Data 6

Thank you Allah engkau telah memberiku sahabat yang begitu baik. Thank you friends. (Thank you God, You have given me nice friends. Thank you friends)

There is outer code-mixing in this data. The student mixes with English in the word thank you and phrase thank you friends. The student uses it because he knows English well and it is popular term to say.

Data 7

Jangan lupa like, share, koment and subscribe. See you on the next video.

(Don't forget to like, share, comment, and subscribe. See you on next video)

Data 7 shows that there is outer code-mixing. The student mixed Indonesian and English in his/her sentence. The student mixes into English because like, share, comment, and subscribe are popular words nowadays and she wants to achieve purpose so that reader can follow her youtube channel.

Data 8 
Aku melihat dia baru bangun tidur "ya ampun ini mah kita bisa telat" kataku. (I see her just wake up, "O my God! it will be late.” I said.

From data 8, it can be found that the sentence contains inner code-mixing. The student uses the word mah. It is from Sundanese and does not have a meaning. Factor that causes to Sundanese is because it is a habit in speaking Sundanese to say that word.

\subsection{Interview Results}

To get valid information about the use of Indonesian and the students' ability in using Indonesian both oral and written, researcher uses question guidelines which have been prepared to help to get valid information. The result of interviewing with principal showed that the school has already used Indonesian as language of communication between school people. Yet, they still mix with the local language such as Sundanese because Sundanese needs to be preserved as part of the Indonesia culture. Meanwhile, interviewing with teacher grade 5, it showed that teacher and students use Indonesia and Sundanese in the classroom while learning but when compared to its use, Indonesian is more often used. It is because most of students come from other provinces who do not know much about Sundanese.

\section{Conclusion}

Based on the results of the study, it can be found that the use of Indonesian in the narrative essay of fifth grade elementary school students in a public school representing Lembang sub-district is still found in bilingual writing, namely code-mixing. Based on data obtained from SDN 1 Kayuambon, it is found 8 data containing code-mixing There are 4 data that contain inner code-mixing, there are 3 data that contain outer codemixing, and there are 2 data that contain code-mixing from formal language to informal. From the existing data there is no mixed code mix. The factors that cause students to mix the code are the speaker or personal of the student, the code is easier to remember, habit factor, the use of terms that are more popular, the function and purpose factors the speaker wants to achieve.

\section{Acknowledgements}

Authors wishing to God Almighty, whom with his willing giving the opportunity to complete this research, to parents who always support and encourage, and all primary education lectures at postgraduate school, Indonesia University of Education.

\section{References}

[1] M.G, Johan, "Profil Kedwibahasaan Siswa Sekolah Dasar Kelas VI SDN 1 Miri Kabupaten Ponorogo," Jurnal Tunas Bangsa, Vol. 5, No. 1, p. 12-21, 2018.

[2] U. Weinrich, Languages in Contact: Findings and Problem. Paris: Mouton, 1970.

[3] L.U Jannah, "Inteferensi Bahasa Indonesia dalam Pemakaian Bahasa Inggris pada Wacana Tulis Siswa" Jurnal EDU-KATA, Vol. 3, No. 1, p.82, 2016. 
[4] B.R. Azmi, "Campur Kode Bahasa Jawa terhadap Bahasa Indonesia dalam Karangan Narasi Sugestif Siswa Kelas VA SDN Ambulu 01 Jember”, Essay, Univeristy of Jember, Jember, 2017.

[5] P.W Kaka, "Interferensi Struktur Kalimat Luas Berunsur Keterangan Bahas Laura Dalam Bahasa Indonesia Tulis Siswa Kelas IV SDK Marsudirini Kecamatan Laura Kabupaten Sumba Barat Daya." Jurnal Ilmiah Pendidikan, Vol. 2, No 1, 2015.

[6] Suparlan, "Campur Kode dalam Karangan Siswa Kelas VI SDN Balongcabe Kecamatan Kedungasem Kabupaten Bojonegoro.” EDU-KATA, Vol. 1, No 2, p. 169178, 2014.

[7] N. Yuliana, "Code-Mixing and Code-Switchingof Indonesian Celebrities: a Comparative Study,” Jurnal Lingua Cultura Vol. 9, No. 1, May 2015.

[8] N. Suandi, Sociolinguistik, Yogyakarta: Graha ilmu, 2014.

[9] N. Indrayani, "Penggunaan Campur Kode dan Alih Kode dalam Proses Pembelajarandi SMPN Ubung Pulau Buru.” Totobuang, Vol. 2, No. 5, p. 229-314, 2017.

[10] R. Hendaryan, "Ekspresi Kesantunan dalam Tuturan Bahasa Indonesia oleh Penutur Dwibahasawan Sunda-Indonesia," dissertation, Indonesia University of Education. Bandung, 2015. 